\title{
PENGUJIAN ORGANOLEPTIK PRODUK YOGURT DENGAN PENAMBAHAN VARIASI KONSENTRASI DAUN KELOR (Moringa oleifera)
}

\author{
Martha Aznury ${ }^{1, *}, Z^{* a m a n}{ }^{1}$, Ahmad Zikri $^{1}$, Panzurli $^{1}$ \\ ${ }^{1}$ Jurusan Teknik Kimia, Politeknik Negeri Sriwijaya \\ Jl. Srijaya Negara Bukit Besar, Palembang 30139 \\ *Email: martha_aznury@polsri.ac.id
}

\begin{abstract}
ABSTRAK
Penelitian ini bertujuan untuk mengetahui berapa persentase penambahan tepung daun kelor dan lama waktu fermentasi untuk menghasilkan yogurt yang berkualitas. Pada pembuatan yogurt ini memvariasikan konsentrasi penambahan tepung daun kelor dan lama waktu fermentasi selama 14 dan 16 jam. Bahan baku yang digunakan adalah susu UHT dengan variasi yang sama untuk semua sampel, sedangkan variasi penambahan tepung daun kelor sebanyak 0, 2, 4, 6 dan 8 gram. Pada pembuatan yogurt ini dilakukan uji organoleptik untuk mengetahui tingkat kesukaan konsumen terhadap penambahan tepung daun kelor yang paling tepat agar dihasilkan formula yogurt daun kelor yang paling baik. Pilihan pada B1 (kontrol), B2 (disukai) dan B5 (tidak disukai).
\end{abstract}

Kata kunci: Yogurt, daun kelor, organoleptik

\begin{abstract}
This study aims to determine what percentage of the addition of Moringa leaf flour and fermentation time to produce quality yogurt. In making this yogurt varies the concentration of the addition of Moringa leaf flour and the length of fermentation time for 14 and 16 hours. The raw material used is UHT milk with the same variation for all samples, while the variation of the addition of Moringa leaf flour is $0,2,4,6$, and 8 grams. In making yogurt, organoleptic tests were performed to determine the level of consumer preference for the addition of the most appropriate Moringa leaf flour to produce the best Moringa leaf yogurt formula. Options on B1 (control), B2 (like) and B5 (dislike).
\end{abstract}

Keyword: Yogurt, moringa leaf, Organoleptic

\section{PENDAHULUAN}

Daun Kelor memiliki kandungan nutrisi yang sangat banyak yang bisa dimanfaatkan sebagai penambah nilai gizi suatu makanan. Daun segar kelor mengandung $92 \mathrm{~g}$ energi, $6,8 \mathrm{~g}$ protein, 1,7 g lemak $440 \mathrm{mg}$ kalsium, $220 \mathrm{mg}$ vitamin $\mathrm{C}$ dan lain-lainnya (Fuglie, 2001).

Yogurt merupakan olahan susu dari hasil fermentasi kedua dari Bakteri Asam Laktat (BAL) sebagai starter, yakni Streptococcus thermophillus dan Lactobacillus bulgaricus yang hidup bersimbiosis. Lama proses fermentasi akan berakibat pada turunnya $\mathrm{pH}$ yogurt dengan rasa asam yang khas, selain itu dihasilkan asam asetat, asetaldehid, dan bahan lain yang mudah menguap. Komposisi yogurt secara umum adalah protein $4-6 \%$, lemak $0,1-1 \%$, laktosa 2$3 \%$, asam laktat $0,6-1,3 \%, \mathrm{pH} 3,8-4,6 \%$ (Susilorini dan Sawitri, 2007).

Kualitas yogurt dapat ditentukan melalui 2 cara yaitu secara subjektif dan pengamatan secara objektif, pengukuran kimia, fisik, dan mikroba. Pengukuran kualitas yogurt dapat berlangsung kapan saja, tetapi biasanya berlangsung sekitar 24 jam setelah produksi dan jika memungkinkan terdiri dari pemeriksaan sensoris (rasa, aroma, penampakan luar, 
tekstur), mikroskopis, titrasi keasaman, $\mathrm{pH}$, komposisional, analisis (lemak, protein) dan ketahanan umur setelah 4 hari penyimpanan pada suhu $15^{\circ} \mathrm{C}$ (Kroger, 2001).

Starter yogurt mengandung bakteri Streptococcus thermophiles dan Lactobacillus bulgaricus dengan perbandingan yang sama (1:1). Streptococcus thermophiles tumbuh lebih cepat dari Lactobacillus bulgaricus (Routray dan Mishra, 2011). Rasio antara Streptococcus thermophiles dan Lactobacillus bulgaricus 1:1 menghasilkan sifat dan aroma yogurt yang paling baik (Ghadge dkk, 2008). Kedua spesies ini bersifat mutual synergism (Masato dkk, 2008).

\section{METODE}

Daun kelor (Moringa oleifera) diambil dari wilayah sekitar Palembang. Peralatan gelas menggunakan merk Pyrex, USA. Daun kelor ini dikeringkan dan dijadikan tepung. Tepung daun kelor ini dijadikan bahan untuk aditif untuk yogurt. Proses pembuatan yogurt menggunakan mikroba Lactobacillus bulgaricus dan Streptococcus Thermophilles dibeli dengan merk dagang Lactina.

Variabel pembuatan yogurt dengan variasi tepung daun kelor antara lain 0,2 , 4,6 , dan 8 gram. Waktu fermentasi antara 14 dan 16 jam. Diberi kode A dan B, seperti Tabel 1., di bawah ini:

Tabel 1. Variabel Penambahan Daun Kelor dan Waktu Fermentasi

\begin{tabular}{c|c|c}
\hline \multirow{2}{*}{ Massa } & \multicolumn{2}{|c}{ Waktu Fermentasi (jam) } \\
\cline { 2 - 3 } Tepung (g) & $\mathbf{1 4}$ & $\mathbf{1 6}$ \\
\hline 0 & A1 & B1 \\
2 & A2 & B2 \\
4 & A3 & B3 \\
6 & A4 & B4 \\
8 & A5 & B5 \\
\hline
\end{tabular}

\section{Pembuatan Yogurt}

a. Susu UHT $200 \mathrm{ml}$ (susu tidak perlu dipanaskan begitu segelnya dibuka bisa langsung dicampurkan dengan
Lactina) kemudian masukan susu tersebut kedalam gelas kimia atau toples kaca.

b. Susu dimasukkan ke dalam gelas kimia atau toples kaca selanjutnya masukkan tepung daun kelor sesuai variasi yang telah ditentukan yaitu $0,2,4,6$, dan 8 gram.

c. Penambahan bakteri Lactina kedalam campuran susu dan tepung daun kelor yang telah disiapkan tadi.

d. Tutup gelas kimia atau toples tersebut dengan aluminium foil dan fermentasi sesuai dengan lama waktu yaitu 14 dan 16 jam.

e. Waktu 14 dan 16 jam fermentasi selesai dan masukkan gelas kimia atau toples kedalam es-batu yang bertujuan untuk mematikan bakteri tersebut setelah itu masukkan ke dalam lemari es.

\section{Pengukuran pH}

Sampel produk yogurt diukur dengan menggunakan $\mathrm{pH}$ meter.

\section{Uji Organoleptik}

Uji organoleptik dilakukan oleh 25 panelis yang terdiri dari mahasiswa Teknik Kimia Politeknik Negeri Sriwijaya. Uji ini dilakukan dengan pemeriksaan dan penilaian sifat fisik yogurt daun kelor (warna, rasa, aroma dan daya terima). Syarat panelis yang mengikuti uji kualitas organoleptik dalam keadaan sehat, dan sedang tidak lapar. Adapun tahap-tahapan yang dilakukan dalam tes organoleptik yaitu :

a) Meminta dan mengumpulkan panelis sebanyak 25 orang.

b) Membagikan formulir kepada panelis, peneliti menjelaskan cara pengisian formulir penilaian produk.

c) Peneliti meminta panelis untuk mengamati, mencoba dan mencium aroma produk yogurt daun kelor dan memberikan penilaiannya.

d) Setelah diamati, mencoba dan 
mencium, aroma produk yogurt, panelis mengisi formulir yang sudah diberikan.

Tes organoleptik itu sendiri bisa dilakukan dengan berbagai macam tes diantaranya:

\section{Uji warna}

$>$ Sampel yogurt diambil secukupnya, kemudian diletakkan di atas gelas arloji yang bersih dan kering.

$>$ Dilihat sampel yogurt beberapa saat, kemudian memberi skor pada masing-masing perlakuan oleh 25 orang panelis.

\section{Uji Aroma}

> Sampel yogurt diambil sebanyak 1 sendok teh dan diletakkan di atas gelas arloji yang bersih dan kering.

> Sampel yogurt dicium pada jarak kira-kira $3 \mathrm{~cm}$ dari hidung untuk mengetahui baunya oleh 25 orang panelis.

\section{Uji Rasa}

$>$ Sampel yogurt diambil kira-kira 1 sendok teh dan dirasakan dengan lidah.

Dilakukan pengerjaan oleh 25 orang panelis.

\section{Uji Tekstur}

$>$ Sampel diambil kira-kira 1 sendok teh dan dirasakan dengan mulut oleh 25 orang panelis.

$>$ Daya terima atau kesukaan.

> Sampel diambil kira-kira 1 sendok teh dan dirasakan dengan mulut oleh 25 orang panelis.

\section{HASIL DAN PEMBAHASAN}

\section{Analisa $\mathrm{pH}$}

Nilai $\mathrm{pH}$ adalah derajat keasaman yang digunakan untuk menyatakan tingkat keasaman atau kebasaan yang dimiliki oleh suatu larutan. Berdasarkan hasil analisa kadar $\mathrm{pH}$ yogurt daun kelor dapat dilihat Gambar 1 berikut :

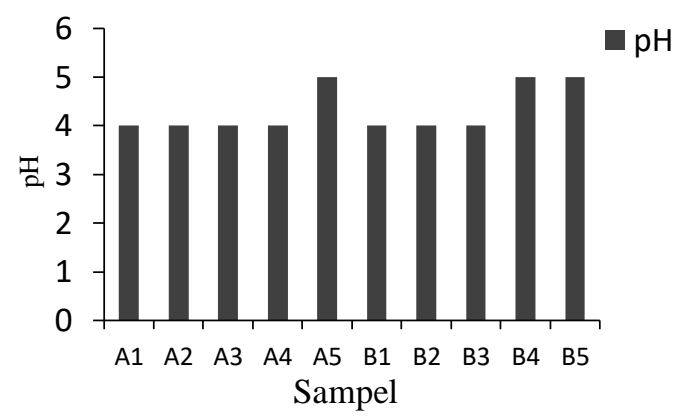

Gambar 1. Grafik Kadar pH Yogurt

Gambar 1 menunjukkan nilai $\mathrm{pH}$ yogurt daun kelor berkisar antara 4-5 sesuai dengan SNI yogurt yaitu nilai $\mathrm{pH}$ harus 3-5. Pada kode A1-A5 nilai $\mathrm{pH}$ stabil pada perlakuan A1, A2, A3, dan A4 secara berturut-turut memiliki nilai $\mathrm{pH} 4$ dan terjadi perubahan pada sampel A5, pH menjadi 5. hal ini masih dalam batas aman yogurt menurut SNI karena tidak melebihi 5. Begitupun dengan perlakuan fermentasi yang 16 jam, nilai $\mathrm{pH}$ yang didapat pun tidak melebihi batas aman yogurt menurut SNI, akan tetapi disini bisa diihat pada grafik bahwa pada sampel dengan kode B4 dan B5 terjadi peningkatan nilai $\mathrm{pH}$ yaitu menjadi 5 , hal ini dikarenakan terjadinya penambahan tepung daun kelor yang signifikan yaitu 6 dan 8 gram. Hal inilah yang diyakini menyebabkan terjadinya perubahan atau peningkatan nilai $\mathrm{pH}$ yang didapat. Pada analisa $\mathrm{pH}$ ini digunakan kertas lakmus yang menyebabkan tidak terlihatnya nilai koma pada $\mathrm{pH}$ yang didapat.

Menurut Kartikasari dan Nisa (2014), selama fermentasi asam laktat yang terbentuk akan disekresikan keluar sel dan terakumulasi dalam media fermentasi sehingga semakin lama waktu fermentasi, jumlah total asam yang terakumulasi semakin meningkat. Selama fermentasi bakteri asam laktat akan mendegradasi laktosa susu menjadi asam laktat sehingga akan berpengaruh 
terhadap $\mathrm{pH}$ yang dihasilkan. Dengan adanya penambahan tepung daun kelor menjadikan $\mathrm{pH}$ yogurt menjadi semakin meningkat dan bisa memungkin $\mathrm{pH}$ yogurt untuk netral seperti pernyataan Fuglie (2001) bahwa pH kelor berkisar antara 5-6.

\section{Analisa Organoleptik}

Uji Organoleptik dilakukan pada 10 sampel produk yogurt dengan menggunakan 25 panelis. Uji organoleptik dimaksudkan guna menilai daya terima atau tingkat kesukaan konsumen terhadap produk. Uji Organoleptik untuk mengetahui tingkat kesukaan dan penerimaan panelis terhadap produk. 10 sampel yang diujikan merupakan produk dengan penambahan $0,2,4,6$, dan 8 gram tepung daun kelor. Uji organoleptik meliputi warna, bau, rasa dan tekstur.

\section{a. Warna}

Kecenderungan kesukaan panelis terhadap warna yogurt dengan berbagai perlakuan dapat dilihat Gambar 2 berikut :

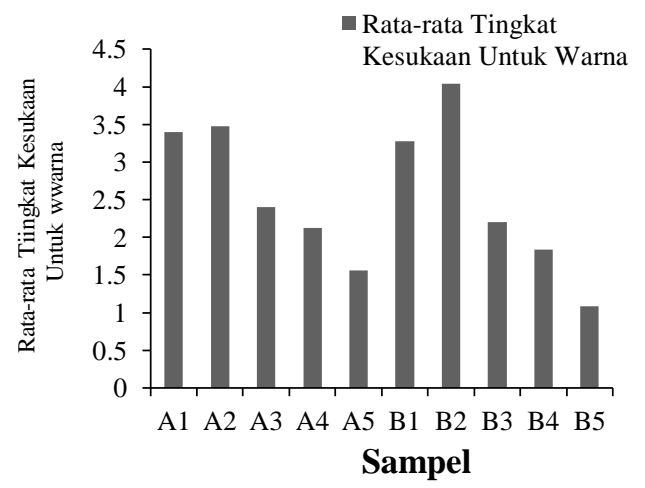

Gambar 2. Grafik Hasil Organoleptik Yogurt Daun Kelor Untuk Warna

Berdasarkan uji organoleptik yang dilakukan oleh 25 panelis bisa terlihat bahwa yang paling disukai adalah sampel dengan kode B2 (Penambahan 2 gram tepung daun kelor dan lama waktu fermentasi selama 16 jam) sedangkan sampel yang paling tidak disukai yaitu sampel dengan kode B5 (Penambahan 8 gram tepung daun kelor dan lama waktu fermentasi selama 16 jam). Sampel B2 memiliki warna hijau muda yang tidak terlalu pekat sedangkan sampel B5 memiliki warna hijau yang sangat pekat. Dari data nilai F Hitung > F Tabel dari hal hasil itu bisa dinyatakan terdapat pengaruh nyata dengan penambahan tepung daun kelor. Semakin banyak penambahan tepung daun kelor akan menghasilkan warna yang semakin pekat.

\section{b. Bau}

Kecenderungan kesukaan panelis terhadap bau yogurt dengan berbagai perlakuan dapat dilihat Gambar 3 berikut :

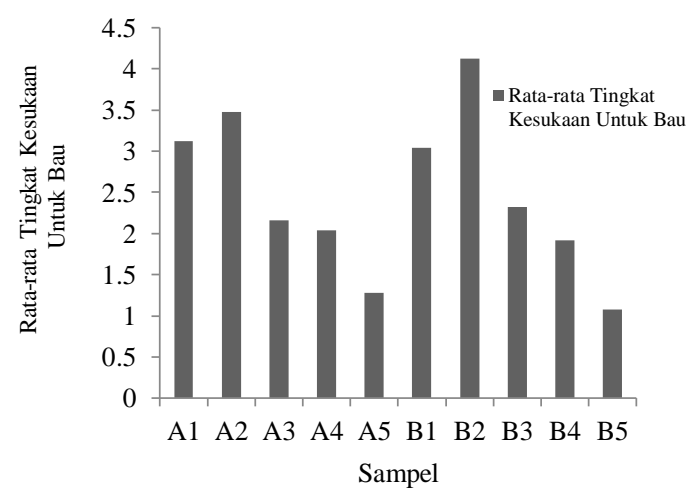

\section{Gambar 3 Grafik Hasil Organoleptik Yogurt Daun Kelor Untuk Bau}

Dari hasil uji organoleptik terhadap 25 panelis, penilaian paling disukai yaitu aroma yogurt daun kelor terdapat pada perlakuan B2 (lama fermentasi 16 jam dan penambahan 2 gram tepung daun kelor) dengan nilai rata-rata sebesar 4,12 sedangkan yogurt yang paling tidak disukai terdapat pada perlakuan B5 (lama fermentasi 16 jam dan penambahan 8 gram tepung daun kelor) dengan nilai rata-rata 1,08 , akan tetapi dari semua sampel yang diuji organoleptik memiliki nilai rata-rata dari 1,08 sampai 4,12 hal inilah yang menyebabkan semakin 
banyak penambahan tepung daun kelor akan membuat bau semakin tajam atau dengan kata lain bau yang dihasilkan sepenuhnya bau daun kelor, hal itu lah yang diyakini sampel B5 merupakan sampel yang paling tidak disukai. Dari hasil data yang diolah nilai $\mathrm{F}$ hitung $>\mathrm{F}$ tabel hal ini terjadi bahwasannya terdapat pengaruh akan penambahan tepung daun kelor.

\section{c. Rasa}

Kecenderungan kesukaan panelis terhadap rasa yogurt dengan berbagai perlakuan dapat dilihat Gambar 4 berikut :

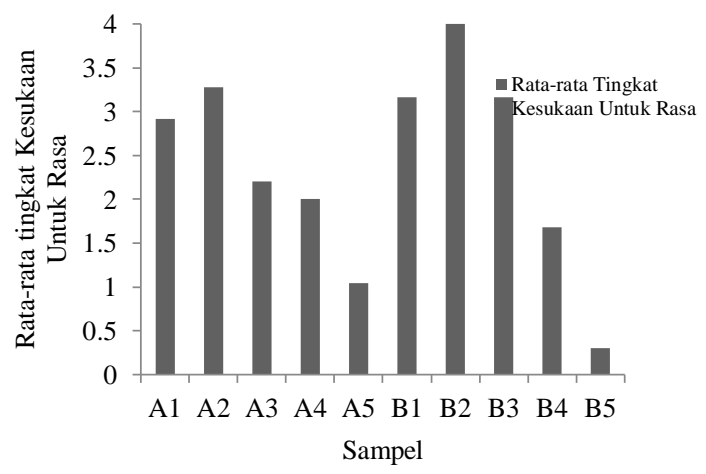

Gambar 4 Grafik Hasil Organoleptik Yogurt Daun Kelor Untuk Rasa

Berdasarkan hasil uji organoleptik yogurt daun kelor terhadap 25 panelis, rasa yang paling disukai terdapat pada sampel B2 (lama fermentasi 16 jam dan penambahan 2 gram tepung daun kelor) sedangkan sampel yang paling tidak disukai merupakan sampel dengan kode B5 (lama fermentasi 16 jam dan penambahan 8gram tepung daun kelor). Dari hasil data yang diolah nilai F hitung $>\mathrm{F}$ Tabel hal ini terjadi bahwasannya terdapat pengaruh akan penambahan tepung daun kelor. Semakin banyak penambahan tepung daun kelor menyebabkan rasa pada yogurt semakin pahit hal inilah yang menyebabkan sampel B5 merupakan sampel yang paling tidak disukai dibandingkan dengan sampel yang lain.

\section{d. Tekstur \\ Kecenderungan kesukaan panelis terhadap tekstur yogurt dengan berbagai perlakuan dapat dilihat Gambar 5 berikut :}

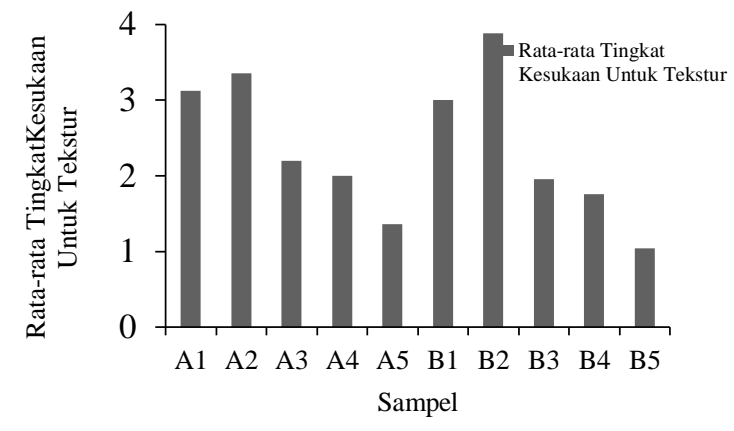

\section{Gambar 5 Hasil Organoleptik Yogurt Daun Kelor :Tekstur}

Berdasarkan hasil uji organoleptik terhadap 25 panelis, sampel dengan kode B2 (lama fermentasi 16 jam dan penambahan 2 gram tepung daun kelor) merupakan penilaian tekstur terbaik atau paling disukai dengan nilai rata-rata 3,88 sedangkan sampel B5 (lama fermentasi 16 jam dan penambahan 8 gram tepung daun kelor) merupakan sampel yang paling tidak disukai dengan nilai rata-rata 1,04. Dari hasil data yang diolah nilai $F$ Hitung > F Tabel hal ini terjadi bahwasannya terdapat pengaruh akan penambahan tepung daun kelor. Dari ke 10 sampel yang di uji organoleptik nilai rata-rata untuk penilaian tekstur berkisar dari 1,04 sampai 3,88. Penambahan tepung daun kelor menyebabkan tekstur yogurt menjadi menggumpal, hal inilah yang mendasari sampel dengan B5 merupakan penilaian panelis yang tidak disukai.

Hasil uji organoleptik yang dilakukan terhadap 25 panelis maka didapatkan hasil yang paling disukai yaitu sampel dengan kode B2 (penambahan 2 gram tepung daun kelor dan lama waktu fermentasi selama 16 jam) sedangkan sampel yang paling tidak disukai yaitu sampel dengan kode B5 
(penambahan 8 gram tepung daun kelor dan lama waktu fermentasi selama 16 jam. Sampel B1 merupakan sampel yang tidak diberi tambahan tepung daun kelor yang digunakan sebagai pembanding kedua sampel lainnya.

\section{SIMPULAN}

Berdasarkan penelitian pembuatan yogurt dengan penambahan variasi konsentrasi daun kelor (Moringa oleifera), dapat disimpulkan bahwa ditinjau dari semua data yang digunakan pada penelitian ini untuk ketiga sampel yang dianalisa berdasarkan hasil uji organoleptik untuk kode sampel B1, B2 dan B5 dengan lama waktu fermentasi selama 16 jam terjadi suatu peningkatan pada semua variabel yang dianalisa. Kode sampel B1 merupakan sampel yang tidak diberi tambahan tepung daun kelor. Kode B2 merupakan sampel yang beri tambahan 2 gram tepung daun kelor dan kode B5 merupakan sampel yang paling banyak diberi tambahan tepung daun kelor yaitu 8gram. Sampel B2 dan B5 merupakan sampel yang paling paling disukai dan sampel yang paling tidak disukai, dikarenakan pada sampel B2 rasa, warna, bau dan tekstur serta hasil dari semua variabel yang dianalisa masih dalam konteks SNI yogurt, selain itu untuk ke empat variabel uji organoleptik masih bisa diterima dikarenakan penambahan tepung daun kelor sebanyak 2gram tidak membuat aneh rasa dari yogurt yang dihasilkan sedangkan sampel dengan kode B5 memiliki rasa yang lebih pahit, warna yang sangat pekat, bau yang sangat tajam dan tekstur yang menggumpal hal inilah yang menyebabkan sampel B5 menjadi tidak disukai panelis.

\section{DAFTAR RUJUKAN}

Fuglie, L.J. 2001. The Miracle Tree: Moringa Oleifera : Natural Nutrition for the Tropis. Training
Manual Church World Service. Dakar: Senegal.

Ghadge, P.N., K.Prasad, dan P.S. Kadam. 2008. Effect of fortification on thephysico-chemical and sensoryproperties of buffalo milk yoghurt. Electron J Environ, Agric Food Chem 7(5): 2890-2899

Haryadi, Nur Kholis. 2011. Kelor Herbal Multikhasiat Ampuh Melawan Diabetes Mellitus, Kolestrol Tinggi dan Penyakit Lainnya. Surakarta : Delta Media.

Kartikasari, D.I. dan Nisa, F.C. 2014. Pengaruh penambahan sari buah sirsak dan lama fermentasi terhadap karakteristik fisik dan kimia yoghurt. Jurnal Pangan dan Agrobisnis 02(04):239-248

Kroger, J. (2001). Identity Development Adolescene Trough Adulthood London: Sage Publication, Inc.

Masato, O., M. Yoshiaki, dan N. Toshihide. 2008. Sensory properties and taste compounds of fermented milk produced by Lactococcus lactis and Streptococcus thermophilus. Food Sci Technol Res 14(2):183-189

Routray, W. dan Mishra, H.N., 2011. Scientific and technical aspects of yogurt aroma and taste: a review. Comprehensive Reviews in Food Science and Food Safety 10(4): 208220

Susilorini, T. E. Dan M. E. Sawitri. 2007. Produk Olahan Susu. Surabaya: Penebar Swadaya

Widodo, W., 2002, Bioteknologi Fementasi Susu, Pusat Pengembangan Bioteknologi Universitas Muhamadiyah, Malang. 